can be at least doubled if crops are harrested when the foliage is at its most lush, not simply when the crop is ready for conventional harvesting. A side benefit is that the land is by this means set free more quickly for resowing. At Rothamsted during 1967-68, an acre produced 1,400 pounds of extracted protein, and in Mysore, where growth continues through the winter, an acre yielded 1.2 tons of the protein.

\section{All Fall Down}

THE National Tower Testing Station is one of the most unusual laboratories in Britain. It is sited in a deep quarry in Somerset, just around the corner from the Cheddar Gorge. Although the station was built by the Central Electricity Generating Board, it will undertake tests of struetures for anybody prepared to pay the quite modest charges. The station offers the opportunity for full scale testing of structures such as electricity transmission towers, which cannot be tested effectively at model scale. Even a small improvement on a tower of which 5,000 examples are to be built can be important, specially if it makes it possible for the tower to be made lighter, with the saving of a ton or so of steel.

The structures to be tested are assembled on the floor of the quarry and firmly anchored to the rock through anchor points. Stresses are applied to the

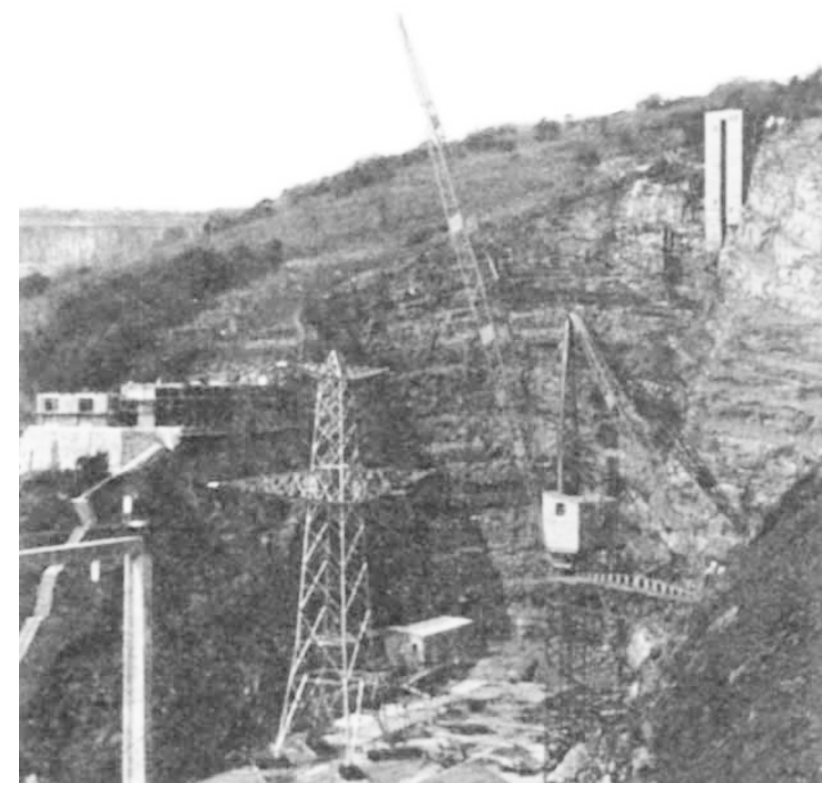

towers through steel wires attached to two rams in the side of the quarry-one can be seen in the pictureand hydraulic rams anchored to the floor. A variety of different tests can be carried out, leading ultimately to a test to destruction which reveals whether or not the structure fulfils specification. The picture shows a new type of $400 \mathrm{kV}$ tower being tested for the CEGB which is only 100 feet high, compared with the 165 feet of the usual $400 \mathrm{kV}$ tower.

Last week, the station tested to destruction a 200 foot tower built for the Atomic Energy Commission of Canada. But it is also capable of testing much smaller structures, such as glass-fibre components or yacht masts. The station is about to begin work on wooden telegraph poles, which have never been systematically tested before. In effect, the station is being used to calibrate the inspectors, who usually decide when a pole shall be condemned on visual appearance alone. The station would also like the chance to test the steel frame structures used for large buildings. A structure up to 13 storeys high could be tested, and, for an expenditure of $\mathfrak{£} 10,000$ to $£ 12,000$, enormously valuable information could be gained. No building structures as large as this have ever been tested in Britain, though they are widely used.

\section{Another Look at CERN}

THe House of Commons Select Committee on Science and Technology has decided to investigate the British Government's decision not to support the CERN $300 \mathrm{GeV}$ machine. The committee, which announced this in a special report last week, will also be investiga. ting fusion research at Culham Laboratory and the development of carbon fibre materials.

These will not be full-blooded investigations on the lines of the present investigation into defence research. Instead, they will be carried out by the General Purposes Sub-Committee of the full committee. The subcommittee has six members - Mr Arthur Palmer (chairman of both the select committee and the sub-committee), Mr Tam Dalyell, Dr Edmund Davies, Mr Eric Iubbock, Mr David Price and Mr Airey Neave. The sub-committee has not yet started work, and nothing very serious is likely to happen until after the recess. $\mathrm{Mr}$ Palmer says that, because of the importance of the investigation into defence research, the committee thought there was a danger of other matters being overlooked. It had therefore decided to set up machinery to make rapid assessments of important issues without going into the elaboration of a full report. On the CERN decision, he points out that "the minister made no statement to the House, and there is no chance of a full debate". In these circumstances, the committee thought it important that it should make an investigation. The immediate intention is to bring all the available documents together and to consider them. If further information is needed, witnesses can, of course, be called. Mr Edward Short, the minister responsible for the decision, is an obvious candidate.

The investigation into Culham follows the last major investigation into the British nuclear power programme. In that report, the committee said that it would be taking a continuing look at fusion research. As for carbon fibres, it seems that the committee was concerned by reports in the press that British firms are not developing carbon fibre technology sufficiently vigorously. Rolls-Royce, one of the companies involved, has denied this. The suggestion has also been made that the Ministry of Technology, dissatisfied by the rate of development, is considering handing the whole problem over to the Harwell Laboratory of the AEA. If there is any truth in these reports, the committee will do well to investigate them. But RollsRoyce, which has already won a major contract on the strength of the new technology, must be feeling understandably bitter that its enthusiasm has already been callod into question.

The other sub-committee of the Select Committee, which has been investigating coastal pollution, has now 